\title{
INTENSIFICATION OF THE PROCESS OF PLASMA-INDUCTION GROWING OF LARGE PROFILED TUNGSTEN SINGLE CRYSTALS
}

\author{
V.O. Shapovalov, O.M. Gnizdylo, V.V. Yakusha, Yu.O. Nikitenko, \\ E.M. Berdnikova, J.A. Khohlova \\ The E.O. Paton Electric Welding Institute of NAS of Ukraine, Kyiv, Ukraine \\ E-mail: shapovalov@paton.kiev.ua
}

The structure of a profiled tungsten single crystal obtained by plasma-induction layer-by-layer growth on a single crystal seed crystal at different deposition rates is investigated. Investigated - microhardness, size of the subgrain structure, angles of misorientation of subgrains, the nature of the distribution of dislocations, etc. A complex of experimental methods of modern physical materials science was used, including light, scanning and transmission microdiffraction electron microscopy. It was found that the ingot is a single crystal body with a crystallographic orientation given by the seed crystal. An increase in the growth rate to $70 \mathrm{~mm} / \mathrm{min}$ leads to an insignificant decrease in microhardness, refinement of the substructure with a uniform distribution of the dislocation density, which makes it possible to obtain tungsten single crystals with a single crystal structure at disorientation angles not exceeding $3^{\circ}$.

\section{INTRODUCTION}

The development of existing power generating devices is impossible without the development of new materials. This applies to both existing energy generators and new devices that use thermonuclear reactions as energy sources, as well as energy sources with thermal emission converters.

Today, in the power engineering of large powers, the most promising direction is associated with controlled thermonuclear fusion, and for reliable energy sources of interplanetary ships and space stations-thermionic converters.

In this regard, tungsten, as the most refractory metal, has the perspective of being used in reactors of the ITERa type, as well as in power plants for powering space objects for long-distance and long-term flights. It should be noted that tungsten has many unique properties over a wide temperature range. In technology, its most widely used properties are high melting point, high density, relatively high thermal conductivity and low coefficient of thermal expansion.

Today, in experimental installations for controlled thermonuclear fusion, the question of lining the inner surface of the chamber remains open. There must be plasma inside the reactor for a long time. In the reactor, a high temperature is created by combination deuterium and tritium. As a result, high-energy neutrons (reaction product) interact with the chamber walls and create a high concentration of radiation defects on the surface of the facing materials. Therefore, these materials have special requirements for thermal stability and radiation resistance.

Analysis of the literature shows that the solubility of almost all hydrogen isotopes in tungsten has a low value. This is especially important since the working medium of the reactor contains deuterium and tritium. The solubility of hydrogen in tungsten is much less than in steels, and even more so in vanadium, titanium and other metals.
Hydrogen practically does not dissolve in tungsten, but is sorbed by structural defects (Frenkel pairs, impurity atoms, dislocations, chemisorption on the surfaces of cavities, gas in cavities). The accumulation of deuterium in polycrystalline tungsten is 4-5 times lower than in the layer during plasma spraying; therefore, the homogeneity and absence of dislocations of the structure are very important. In addition to the purity of the metal, special requirements are imposed on the structure of metallic tungsten. Therefore, a single crystal with a given orientation of the crystal lattice is an ideal structure [1, 2].

One of the most promising methods for producing large profiled tungsten single crystals is additive surfacing using plasma-induction heating. This method was developed at the E.O. Paton Electric Welding Institute of the National Academy of Sciences of Ukraine, a technology and equipment for growing large single crystals of refractory metals has been created [3-7]. The peculiarities of this technology include the presence of two independent sources of thermal energy, which make it possible to control the temperature field of a single crystal during its growth using 3D technology. The developed technology shows the best result in relation to world analogues [8-11].

Unfortunately, the technology is energy intensive. At the moment, there is no information on the effect of changes in a wide range of parameters of the technological process of plasma-induction growing on the structure of the obtained single crystals and, accordingly, on the operational properties of single crystal ingots. Taking this into account, intensification of the process of growing single crystals is becoming an urgent topic for research.

The aim of this work is to evaluate the effect of the rate of plasma-induction growth on the structural perfection of single crystal tungsten ingots. 


\section{MATERIALS AND RESEARCH METHODS}

The object of research is a flat tungsten ingot grown using plasma induction technology. Growth was carried out on a single crystal seed crystal oriented in the (110) plane using drop melting of $8 \mathrm{~mm}$ diameter consumable rods.

The power of the plasma arc was $19 \ldots 20 \mathrm{~kW}$, and the power of the high-frequency heater was $90 \ldots 95 \mathrm{~kW}$. For research, a single crystal was grown in accordance with the surfacing modes given in Table 1 (Fig. 1,a,b). After each change in the surfacing mode (see Fig. 1,c), five layers were grown, except for mode $F$ (the maximum surfacing speed was $70 \mathrm{~mm} / \mathrm{min}$ ). Only three layers were deposited at maximum speed.

Table 1

\begin{tabular}{|c|c|c|c|}
\hline $\begin{array}{l}\text { Growing } \\
\text { direction }\end{array}$ & Mode & $\begin{array}{c}\text { Growing } \\
\text { speed } \\
\mathrm{V}, \mathrm{mm} / \mathrm{min}\end{array}$ & $\begin{array}{l}\text { Quantity } \\
\text { of layers }\end{array}$ \\
\hline \multirow{4}{*}{ Top } & $\mathrm{F}$ & $70(\max )$ & 3 \\
\hline & $\mathrm{E}$ & 57 & 5 \\
\hline & $\mathrm{D}$ & 46 & 5 \\
\hline & $\mathrm{C}$ & 36 & 5 \\
\hline \multirow{2}{*}{ Bottom } & $\mathrm{B}$ & 26 & 5 \\
\hline & A & 17 (min) & 5 \\
\hline
\end{tabular}
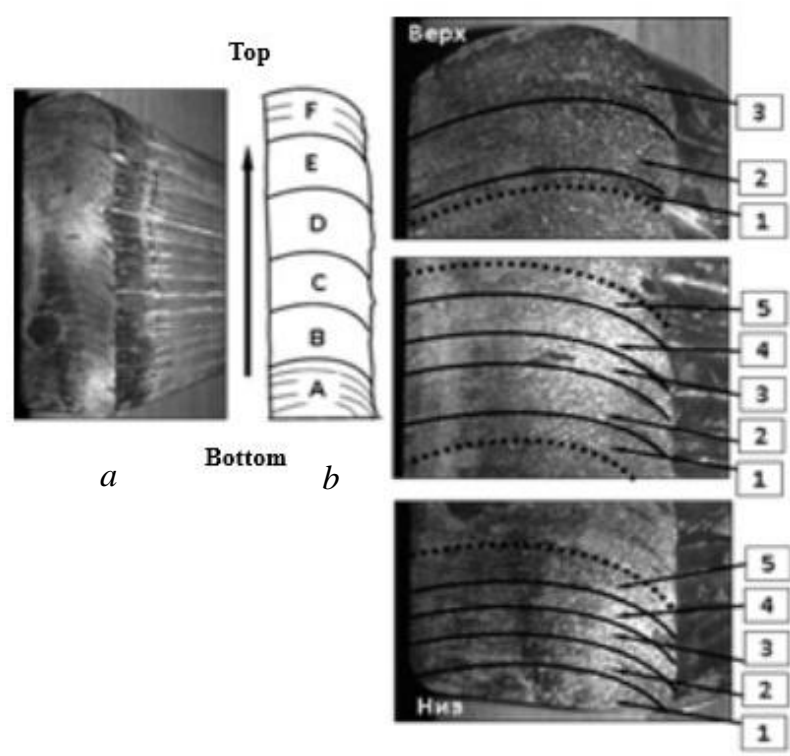

$c$

Fig. 1. General view of a single crystal tungsten ingot (a); its schematic representation in cross-section with indication of growth modes $(A-F)(b)$, and the

macrostructure of the ingot at different speeds (c)

Studies of the structure (microhardness, sizes of subgrain structures and their angles of disorientation, the nature of the distribution of dislocations, etc.) were carried out at all structural levels using a set of experimental methods of modern physical metallurgy, including: optical metallography (Neophot-32 and Versamet-2, Japan; Leco-M400, USA), analytical scanning electron microscopy (SEM) (Philips SEM-515, Netherlands), as well as transmission microdiffraction electron microscopy (JEM-200CX from JEOL $200 \mathrm{kV}$, Japan). For indentation and determination of microhardness and Young's modulus, a "Microngamma" device was used.

The preliminary preparation of samples (obtaining foils) for studies by the method of transmission electron microscopy was carried out in several stages. Electroerosive cutting was performed to cut the sample into plates with a thickness of $0.4 \ldots 0.5 \mathrm{~mm}$, from which washers with a diameter of $3 \mathrm{~mm}$ were obtained. After mechanical thinning of the washers to a thickness of $100 \ldots 120 \mu \mathrm{m}$ on grinding papers, the washers were electrolytically thinned (electropolished) using equipment for producing thin metal foils, then final thinning with ionized argon flows in a VUI-5 vacuum universal installation.

Thus, thin foils for transmission microscopy were prepared by a two-stage method - preliminary electropolishing followed by multiple thinning by ionized argon flows.

\section{RESEARCH RESULTS}

In the course of the research carried out, it was found that the height of the layers being built up (on a $20 \mathrm{~mm}$ wide edge) is $2 \ldots 3 \mathrm{~mm}$. The layer structure is homogeneous, no defects and pores are observed. The etching pits formed on the surface have the same faceting over the entire height of the single crystal ingot, which indicates the identity of the crystallographic orientation in different parts of the ingot (Fig. 2).

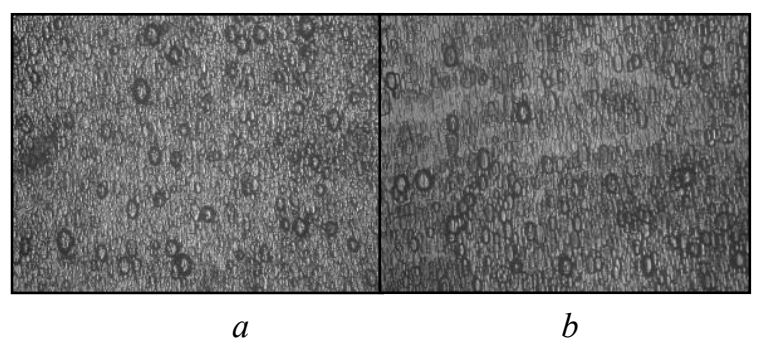

Fig. 2. Microstructure $(\times 100)$ of the cross-section of a monocrystalline tungsten ingot grown at different speeds, $\mathrm{mm} / \mathrm{min}: a-17 ; b-70$

When passing from the minimum growth rate of the single crystal layer $\left(\mathrm{V}_{\min }=17 \mathrm{~mm} / \mathrm{min}\right)$ to the average $\left(\mathrm{V}_{\mathrm{av}}=46 \mathrm{~mm} / \mathrm{min}\right)$, and maximum $\left(\mathrm{V}_{\max }=70 \mathrm{~mm} / \mathrm{min}\right)$, the microhardness of the metal $\mathrm{HV}_{0.5}$ slightly decreases (on average by $4 \ldots 6 \%$ ) from $4290 \ldots 4400$ to $4110 \ldots 4220$ and $4010 \ldots 4200 \mathrm{MPa}$, respectively.

As a result of ion etching of a tungsten single crystal (in the cross section), the substructure in the layers under study appears rather well (Fig. 3). When passing from the minimum speed growing to the maximum, the substructure becomes smaller (on average by 1.3 times), the size of subgrains is, $\mu \mathrm{m}: d_{c}=20 \ldots 32$ (see $V_{\text {min }}$, Fig. 3,a); $\mathrm{d}_{\mathrm{c}}=18 \ldots 25\left(\mathrm{~V}_{\mathrm{av}}\right) ; \mathrm{d}_{\mathrm{c}}=15 \ldots 25\left(\right.$ see $\mathrm{V}_{\max }$, Fig. 3,b).

For the purpose of a deeper and more detailed analysis of the structural features (distribution of crystal lattice defects, formation of dislocation inhomogeneities, misorientation angles during the formation of a substructure) to assess the degree of perfection of a single crystal ingot obtained at different speeds, a transmission study of the fine structure of the monocrystal cross-section was carried out. 


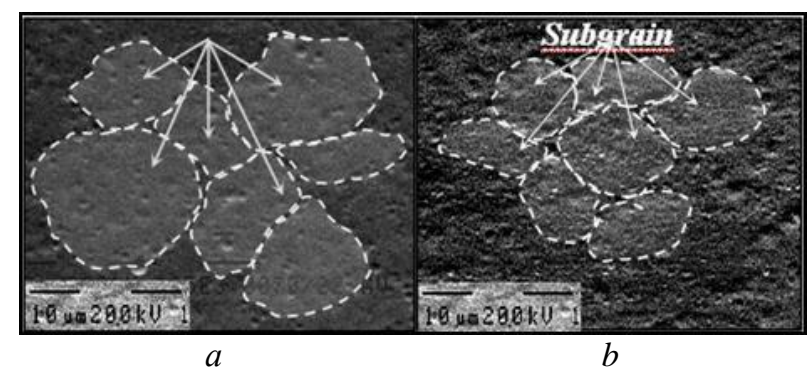

Fig. 3. The microstructure (SEM) of subgrain boundaries I/II ( $\times 25000), \mathrm{mm} / \mathrm{min}$ :

$$
a-17 ; b-70
$$

The measurement of the scalar dislocation density was carried out using the secant method [12], which is used for a fairly uniform distribution of dislocations. The cutting lines formed a rectangular grid. The dislocation density in micrographs was determined using the following dependence:

$$
\rho=\frac{M}{t}\left(\frac{n_{1}}{L_{1}}+\frac{n_{2}}{L_{2}}\right),
$$

where $M$ is the magnification in the micrograph; $t$ is the thickness of the foil; $n_{1}, n_{2}$ - the number of links with horizontal and vertical lines, respectively; $L_{1}, L_{2}-$ total length of horizontal and vertical lines.

Measurements for calculating the dislocation density ( $\rho$ ) were performed with an increase of at least $x 25000$. This increase is sufficient to observe individual dislocations.

Investigation of the fine structure in transmission at $\mathrm{V}_{\min }$ showed that the distribution of dislocations in the volume of the single crystal is mainly uniform (Fig. 4).

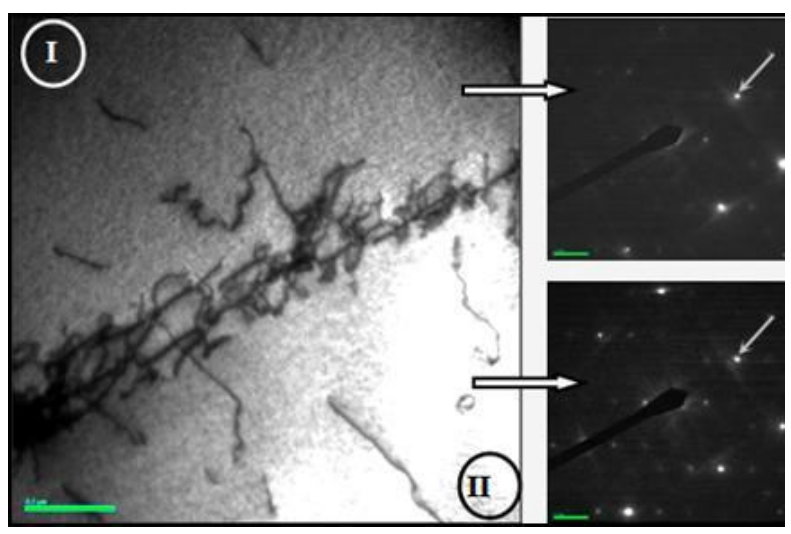

Fig. 4. The dislocation structure $V_{\min }$ (transmission selected-area diffraction electron microscopy) of subgrain boundaries I/II $(\times 25000)$ and

microelectrongrams from neighboring subgrains

The dislocation density $(\rho)$ is $(4 \ldots 6) \cdot 10^{7} \mathrm{~cm}^{-2}$. However, zones with the minimum distribution of the dislocation density at $(2 \ldots 4) \cdot 10^{6} \mathrm{~cm}^{-2}$ and the maximum up to $(2 \ldots 3) \cdot 10^{8} \mathrm{~cm}^{-2}$ were recorded (Table 2). The nature of the dislocation structure is also different. Irregular dislocation accumulations can be traced against the background of slip bands (SB) of dislocations and dislocation loops characteristic of the internal volume of a metal. Subboundaries also have inhomogeneities in the form of dislocation tangles with an increase in the dislocation density from $\rho=(2 \ldots 4) \cdot 10^{8}$ to $\rho=10^{9} \mathrm{~cm}^{-2}$. In this case, gradients in the dislocation density (SD) are observed between the internal volumes of subgrains $\left(\rho=(2 \ldots 4) \cdot 10^{6} \mathrm{~cm}^{-2}\right)$ and their boundaries $\left(\rho=10^{9} \mathrm{~cm}^{-2}\right)$.

When passing to the deposition rates $\mathrm{V}_{\mathrm{av}}$ and $\mathrm{V}_{\max }$ (Fig. 5), the density of dislocations with their uniform distribution over the entire volume of the metal is $(1 \ldots 2) \cdot 10^{8}$ and $(2 \ldots 3) \cdot 10^{8} \mathrm{~cm}^{-2}$, respectively.

The character of the dislocation structure is uniform: dislocation loops have a clear relief, dislocations of different signs are clearly visible, which move in opposite directions, which indicates their possible annihilation. The substructure has clear subboundaries with a homogeneous dislocation structure without dislocation density gradients. There are no dislocation density gradients between the internal volume of grains and grain boundaries. Slide lines of moving dislocations in another plane intersect subboundaries, which, accordingly, do not lead to their pileups. The formation of structures of this type contributes to an increase in the possibilities of plastic relaxation of internal stresses in the metal of the sample under study.

Table 2

\begin{tabular}{|c|c|c|c|c|}
\hline $\begin{array}{c}\text { Growing } \\
\text { speed V, } \\
\mathrm{mm} / \mathrm{min}\end{array}$ & $\begin{array}{c}\text { Structural } \\
\text { zone }\end{array}$ & $\begin{array}{c}\rho(\mathrm{min}), \\
\mathrm{cm}^{-2}\end{array}$ & $\begin{array}{c}\rho(\max ), \\
\mathrm{cm}^{-2}\end{array}$ & $\begin{array}{c}\theta, \\
\mathrm{deg} .\end{array}$ \\
\hline \multirow{2}{*}{17} & subgrain & $(2 \ldots 4) \cdot 10^{6}$ & $(2 \ldots 3) \cdot 10^{8}$ & - \\
\cline { 2 - 5 } & boundaries & $(2 \ldots 4) \cdot 10^{8}$ & $1 \cdot 10^{9}$ & $\begin{array}{c}0.294 \ldots \\
0.920^{\circ}\end{array}$ \\
\hline \multirow{2}{*}{46} & subgrain & $(1 \ldots 2) \cdot 10^{8}$ & $(1 \ldots 2) \cdot 10^{8}$ & - \\
\cline { 2 - 5 } & boundaries & $(3 \ldots 5) \cdot 10^{8}$ & $(5 \ldots 7) \cdot 10^{8}$ & $\begin{array}{c}0.211 \ldots \\
0.855^{\circ}\end{array}$ \\
\hline \multirow{2}{*}{70} & subgrain & $(2 \ldots 3) \cdot 10^{8}$ & $(2 \ldots 3) \cdot 10^{8}$ & - \\
\cline { 2 - 5 } & boundaries & $(4 \ldots 6) \cdot 10^{8}$ & $(6 \ldots 8) \cdot 10^{8}$ & $\begin{array}{c}0.495 \ldots \\
1.923^{\circ}\end{array}$ \\
\hline
\end{tabular}

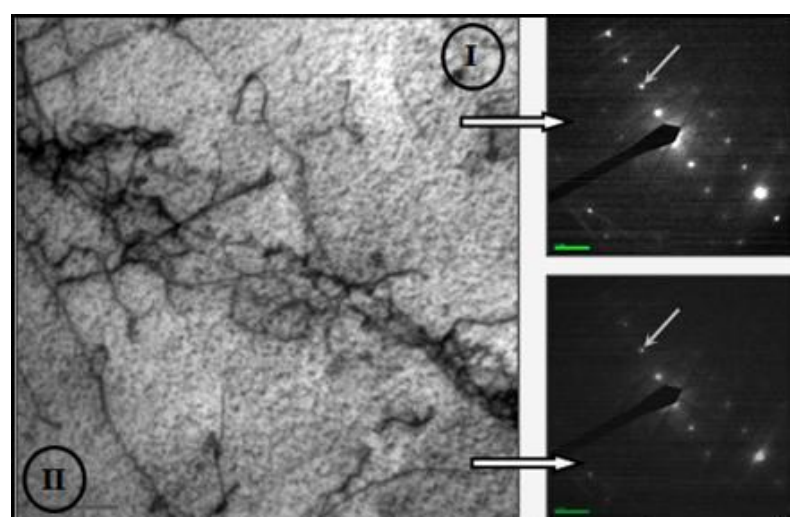

Fig. 5. Dislocation structure at $V_{\max }$ (transmission selected-area diffraction electron microscopy) of subgrain boundaries I/II $(\times 25000)$ and

microelectrongrams from neighboring subgrains

The dislocation density $(\rho)$ is $(4 \ldots 6) \cdot 10^{7} \mathrm{~cm}^{-2}$. However, zones with the minimum distribution of the dislocation density at $(2 \ldots 4) \cdot 10^{6} \mathrm{~cm}^{-2}$ and the maximum up to $(2 \ldots 3) \cdot 10^{8} \mathrm{~cm}^{-2}$ were recorded (see Table 2 ). The nature of the dislocation structure is also different. Irregular dislocation accumulations can be traced against the background of slip bands of dislocations and 
dislocation loops characteristic of the internal volume of a metal.

To assess the structural perfection of a single crystal ingot obtained in different growth modes, the most significant evaluation criterion was used, i.e. The angles of misorientation of subgrains $(\theta)$ were calculated (see Table 2).

The most accurate method for determining the angles of disorientation of subgrains (especially for lowangle boundaries) is the method of transmission selected-area diffraction electron microscopy with subsequent calculation of the obtained diffraction patterns (microelectron diffraction patterns) from neighboring subgrains. According to the method, the complete disorientation of subgrains includes the azimuthal $(\Delta \vec{\alpha})$ and horizontal $\left(\vec{\omega}_{\mathrm{g}}\right)$ components:

$$
|\omega|=\sqrt{|\Delta \alpha|^{2}+\left|\omega_{\Gamma}\right|^{2}} .
$$

The azimuth component of disorientation $(\Delta \vec{\alpha})$ is measured on microelectron diffraction patterns if the subgrains give separate reflections, the distance between which is $\Delta \mathrm{a}$, that is, the displacement of the same reflex from subgrain I relative to the reflex from subgrain II, and the equation looks as follows:

$$
\Delta \alpha=\frac{\Delta a}{\left|\overline{r_{h k l}}\right|} \mathrm{rad},
$$

where $\overline{r_{h k l}}$ is the radius vector of the reflex, the distance from the central beam to the reflex.

Thus, the distances between the two spots (traces of the primary beam) and between the two positions of the reflections $h^{\prime} k^{\prime} l$ ' and $h^{\prime \prime} k^{\prime \prime} l$ " are measured with the maximum available accuracy. The difference of these distances $\Delta a$ makes it possible to calculate $\Delta \vec{\alpha}$.

The horizontal $\left(\vec{\omega}_{\mathrm{g}}\right)$ component of disorientation was found from the relative displacement $(\Delta \delta)$ of the Kikuchi-line pattern plotted on the electron diffraction patterns from neighboring subgrains according to the method [13].

In order to increase the accuracy of graphically processed diffraction patterns, the process of calculating the angles of disorientation of subgrains was automated. A program was specially created in the mathematical package Mathcad, which made it possible to process diffraction patterns.

The calculation of the angles of disorientation $(\theta)$ from the diffraction patterns from the elements of the substructure showed that both for $\mathrm{V}_{\text {min }}$ and $\mathrm{V}_{\mathrm{av}} \theta<1^{\circ}$ (Table 3). In the case of $\mathrm{V}_{\max }$, the angle of disorientation of subgrains increases to $1.923^{\circ}$, but this value does not exceed the allowable value $\theta<3^{\circ}[14]$.

Thus, it has been shown that modes with average $V_{\text {av }}$ and maximum $\mathrm{V}_{\max }$ growth rates lead to a slight decrease in microhardness, substructure refinement by 1.3 times with a uniform distribution of dislocation density $(1 \ldots 2) \cdot 10^{8}$ and $(2 \ldots 3) \cdot 10^{8} \mathrm{~cm}^{-2}$, respectively, and obtaining tungsten single crystals with a perfect single crystal structure (with low-angle boundaries) at disorientation angles not exceeding $3^{\circ}$. At the same time, the transition from the minimum rates to the average and maximum growth rates can significantly reduce the time for obtaining an ingot.

\section{ANALYTICAL ASSESSMENT OF CRACK RESISTANCE OF A SINGLE CRYSTAL TUNGSTEN INGOT}

To assess the fracture toughness of a single crystal ingot of tungsten, analytical estimates of the level of local internal stresses $\left(\tau_{l / i n}\right)$ were made taking into account the distribution of the density of dislocations $(\rho)$ (see Table 3).

There are many different approaches to the mechanism of crack initiation and destruction of materials. We have chosen an estimate based on the dislocation theory of crystalline solids taking into account the nature of the dislocation structure and the distribution of dislocations (accumulation or uniform distribution of dislocations). In this case, the field of internal stresses created by the dislocation structure (dislocation density) is determined by the relationship $\tau_{l / i n}=G b h \rho /[n(1-v)] \tau_{l / i n}=G b h \rho$, where $G$ is the shear modulus; $b$ is the Burgers vector; $h$ is the thickness of the foil; $v$ - poisson's ratio; $\rho$ is the dislocation density.

Table 3

Local internal stresses $\left(\tau_{l / \text { in }}\right)$ in the structural zones of a tungsten single crystal under different growing modes

\begin{tabular}{|c|c|c|c|c|}
\hline $\begin{array}{c}\text { Growing } \\
\text { speed, } \\
\mathrm{mm} / \mathrm{min}\end{array}$ & $\begin{array}{c}\text { Structural } \\
\text { zone }\end{array}$ & $\begin{array}{c}\tau_{l / \text { min } \min }, \\
\mathrm{MPa}\end{array}$ & $\begin{array}{c}\tau_{\text {l/in } \max }, \\
\mathrm{MPa}\end{array}$ & $\begin{array}{c}\Delta \tau_{\text {l/in }}, \\
\mathrm{MPa}\end{array}$ \\
\hline 17 & $\begin{array}{c}\text { subgrain } \\
\text { boundaries }\end{array}$ & $\begin{array}{c}0.1 \ldots 0.2 \\
8 \ldots 17\end{array}$ & $\begin{array}{c}8 \ldots 13 \\
42\end{array}$ & $40 \ldots 42$ \\
\hline 70 & $\begin{array}{c}\text { subgrain } \\
\text { boundaries }\end{array}$ & $\begin{array}{c}8 \ldots 13 \\
17 \ldots 25\end{array}$ & $\begin{array}{c}8 \ldots 13 \\
25 \ldots 33\end{array}$ & $17 \ldots 20$ \\
\hline
\end{tabular}

As a result of the performed estimates, it was found that the zones with the highest values of local internal stresses $\tau_{/ / i n}$ (up to $42 \mathrm{MPa}$ ) are formed under conditions of minimum $\left(\mathrm{V}_{\min }\right)$ growth rates along subgrain boundaries in places of dislocation accumulations $(\rho=$ $10^{9} \mathrm{~cm}^{-2}$ ). A decrease in the values of $\tau_{/ / i n}$ along the boundaries of subgrains is characteristic of the maximum $\left(\mathrm{V}_{\max }\right)$ growth rate $\left(\tau_{l / i n}=17 \ldots 33 \mathrm{MPa}\right)$, which is facilitated by a uniform distribution of the dislocation density (Fig. 6), which is associated with a more diffuse structure of the boundary.

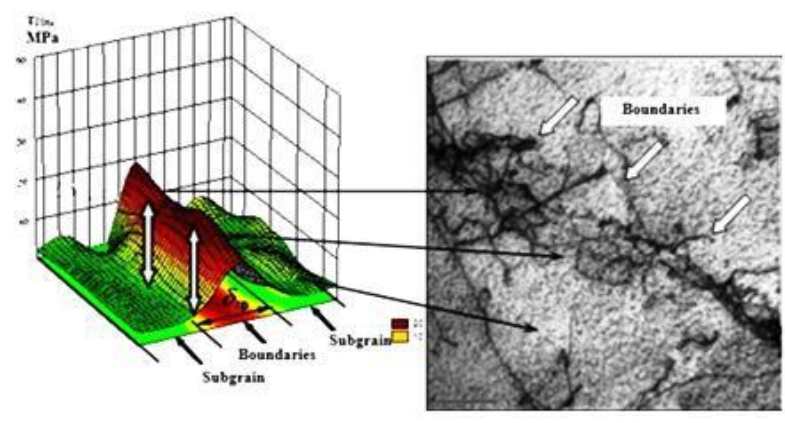

Fig. 6. Distribution of local internal stresses $\left(\tau_{l / \text { in }}\right)$ and their gradients $\left(\Delta \tau_{l / i n}\right)$ in the substructure $(\times 25000)$ of a single crystal tungsten ingot at $V_{\max }$

The result of indentation is to obtain a record of the diagram of continuous indentation of the indenter in the load-unloading mode and software computer calculation of the values of Meyer microhardness, Young's modulus 
of elasticity, plasticity coefficient, etc. characteristics, which allows to obtain the value of unrecovered stiffness and excludes the influence of elastic recovery of the material on the actual value of microhardness [15].

The depth is fixed both at maximum immersion (the value of the surface rigidity is obtained for calculating $\mathrm{H})$, and after the elastic recovery of the material when the load is removed (it gives the value of the elastic reaction of the material (E) without taking plastic deformation into account). The load on the indenter during testing was 100 and $200 \mathrm{~g}$, the indentation step was $100 \mu \mathrm{m}$ (Fig. 7).

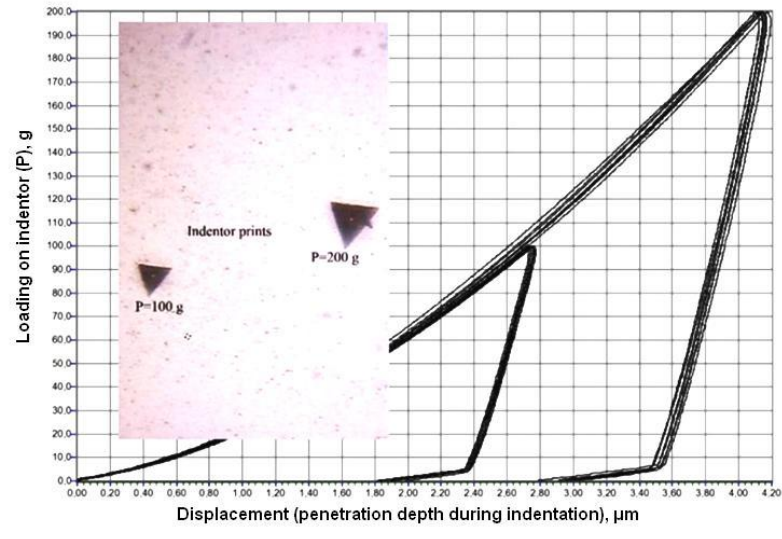

Fig. 7. Indentation diagrams at 100 and $200 \mathrm{~g}$ of load on the indenter

As a result of the research, an almost uniform distribution of microhardness and Young's modulus (deviations within 5\%) was established, which suggests that certain physical and mechanical properties of single crystals have a weak dependence on their growth rate. The average values of microhardness and elastic modulus were 6.2 and $180 \mathrm{GPa}$, respectively.

\section{CONCLUSIONS}

The structure of a large profiled tungsten ingot obtained by the method of additive plasma-induction layer-by-layer growth on a single crystal seed crystal at different growth rates has been investigated. It is shown that the ingot is a monocrystalline body with a given crystallographic orientation.

It was found that the structure is uniform over the entire height of the ingot. It is shown that an increase in the growth rate leads to an insignificant decrease in the microhardness and refinement of the substructure with a uniform (gradientless) distribution of the dislocation density.

The uniform distribution of dislocations in different sections of the ingot and the absence of extended dislocation accumulations - potential concentrators of internal stresses (zones of initiation and propagation of cracks) are established. This contributes to an increase in the fracture toughness of the material under operating conditions.

\section{REFERENCES}

1. D.V. Orlinski, K.Yu. Vukolov, V.S. Voitsenya. Imitation study of mirrors behavior in diagnostic systems of an experimental fusion reactor // Problems of Atomic Science and Technology. Series “Thermonuclear fusion”. 2005, v. 3, p. 3-50.

2. Michael Rieth, Russell Doerner, Akira Hasegawa, Yoshio Ueda, Marius Wirtz. Behavior of tungsten under irradiation and plasma interaction // Journal of Nuclear Materials. 2019, v. 519, p. 334-368.

3. V.A. Shapovalov, A.A. Kovalenko, Yu.V. Latash, et al. Study of the process of growing flat single crystals of tungsten and molybdenum // Problems of Special Electrometallurgy. 1993, N 1, p. 79-82.

4. V.A. Shapovalov, V.V. Yakusha, A.N. Gnizdylo, Yu.A. Nikitenko. Application of additive technologies for growing large profiled single crystals of tungsten and molybdenum // The Paton Welding Journal. 2016, N 5-6, p. 134-136.

5. B.Ye. Paton, V.A. Shapovalov, G.M. Grigorenko, et al. Plasma-induction growing of profiled single crystals of refractory metals. Kiev, 2016, 216 p.

6. V.O. Shapovalov, I.V. Sheiko, V.V. Yakusha, O.M. Gnizdylo, Yu.O. Nikitenko. Innovative technology and equipment for growing super-large single crystals of metals // Electrometallurgy Today. 2020, N 1, p. 26-31.

7. V.O. Shapovalov, Yu.O. Nikitenko, V.V. Yakusha, O.M. Gnizdylo, I.V. Sheiko. Manufacture of super large tungsten single crystals in the form of rotation bodies // Problems of Atomic Science and Technology. 2020, N 1(125), p. 60-63.

8. G. Marinelli, F. Martina, H. Lewtas, D. Hancock, S. Mehraban, N. Lavery, S. Ganguly, S. Williams. Microstructure and thermal properties of unalloyed tungsten deposited by Wire+Arc Additive Manufacture // Journal of Nuclear Materials. 2019, v. 522, p. 45-53.

9. Tsubasa Todo, Takuya Ishimoto, Ozkan Gokcekaya, Jongyeong Oh, Takayoshi Nakano. Single crystalline-like crystallographic texture formation of puretungsten through laser powder bed fusion // Scripta Materialia. 2022, v. 206, p. 114252.

10. X. Shu, S. Xiao, H. Deng, L. Ma, W. Hu. Atomistic simulation of crack propagation in single crystal tungsten under cyclic loading // Journal of Materials Research. 2017, v. 32(8), p. 1474-1483.

11. T. Suzudo, T. Tsuru. Inclination of selfinterstitial dumbbells in molybdenum and tungsten: A first-principles study // AIP Advances. 2021, v. 11, p. 065012; https://doi.org/10.1063/5.0048740.

12. Transmission electron microscopy of metals / By Gareth Thomas. New York-London, Wiley, 1962, 299 p.

13. Electron microscopy of thin crystals / By P.B. Hirsch, A. Howie, R.B. Nicholson. 1965, 558 p.

14. N.P. Lyakishev, G.S. Burkhanov. Metallic single crystals. M.: ELIZ, 2002, 312 p.

15. Iu.A. Khoklova, D.A. Ishchenko, M.A. Khokhlov. Indentation from macro- to nanometer level and examples of investigation of properties of materials with a special structure // Technical Diagnostics and NonDestructive Testing. 2017, N 1, p. 30-36. 


\title{
ИНТЕНСИФИКАЦИЯ ПРОЦЕССА ПЛАЗМЕННО-ИНДУКЦИОННОГО ВЫРАЩИВАНИЯ КРУПНЫХ ПРОФИЛИРОВАННЫХ МОНОКРИСТАЛЛОВ ВОЛЬФРАМА
}

\author{
В.А. Шаповалов, А.Н. Гниздыло, В.В. Якуша, Ю.А. Никитенко, \\ Е.М. Бердникова, Ю.А. Хохлова
}

Исследована структура профилированного монокристалла вольфрама, полученного способом плазменноиндукционного послойного выращивания на монокристаллическом зародышевом кристалле при различных скоростях наплавки. Исследованы - микротвердость; размеры субзеренной структуры, углов разориентирования субзерен; характер распределения дислокаций и т. Д. Использован комплекс экспериментальных методов современного физического материаловедения, включая световую, растровую и просвечивающую микродифракционную электронную микроскопии. Установлено, что слиток является монокристаллическим телом с кристаллографической ориентацией, заданной зародышевым кристаллом. Увеличение скорости выращивания до 70 мм/мин приводит к незначительному уменьшению микротвердости, измельчению субструктуры при равномерном распределении плотности дислокаций, что позволяет получать вольфрамовые монокристаллы с монокристаллической структурой при углах разориентации, не превышающих $3^{\circ}$.

\section{ІНТЕНСИФІКАЦІЯ ПРОЦЕСУ ПЛАЗМОВО-ІНДУКЦІЙНОГО ВИРОЩУВАННЯ КРУПНИХ ПРОФІЛЬОВАНИХ МОНОКРИСТАЛІВ ВОЛЬФРАМУ}

\section{В.О. Шаповалов, О.М. Гніздило, В.В. Якуша, Ю.О. Никитенко, О.М. Бердникова, Ю.А. Хохлова}

Досліджено структуру профільованого монокристала вольфраму, отриманого способом плазмовоіндукційного пошарового вирощування на монокристалічному зародковому кристалі при різних швидкостях наплавки. Досліджено - мікротвердість; розміри субзеренної структури, кутів розорієнтування субзерен; характер розподілу дислокацій та ін. Застосовано комплекс експериментальних методів сучасного фізичного матеріалознавства, включаючи світлову, растрову та просвічуючу мікродифракційну електронну мікроскопії. Встановлено, що зливок є монокристалічним тілом з кристалографічною орієнтацією, яка була задана зародковим кристалом. Збільшення швидкості вирощування до 70 мм/хв призводить до незначного зменшення мікротвердості, подрібнення субструктури при рівномірному розподілі щільності дислокацій, що дозволяє отримувати монокристали вольфраму з монокристалічною структурою при кутах розорієнтації, що не перевищують $3^{\circ}$. 